\title{
Effect of Health Insurance on Demand for Outpatient Medical Care in Rwanda: An Application of the Control Function Approach \\ DOI: http://dx.doi.org/10.4314/rj.v3i1.6B
}

Ruhara Mulindabigwi Charles, University of Rwanda

Urbanus Mutuku Kioko, University of Nairobi

\begin{abstract}
In the 2000's the Government of Rwanda initiated health sector reforms aiming at increasing health care access. Despite these reforms there has not been a corresponding increase in demand for health services, as only about 30 percent of the sick persons use modern care (NISR, 2011). The objective of this paper is to examine factors influencing outpatient care demand in Rwanda and suggest appropriate measures to improve utilization of health services. The source of data is the Integrated Household Living Conditions Survey (EICV2) conducted in 2005 by the National Institute of Statistics Rwanda (NISR). A structural model of demand for health care is estimated to measure demand effects of covariates. The findings indicate that health insurance is a significant determinant of outpatient medical care. In addition, price of health care and household income are among the main drivers of utilization of health care. Being female is found to increase the probability of seeking outpatient health care. Two main policy recommendations emerge from these findings. First, the government should reduce out-of-pocket health care expenditures (OOPE) through subsidies to public health facilities. Second, the government should reduce the premiums for Community Based Health Insurance Schemes (CBHIs) to increase the coverage rate.
\end{abstract}

Keywords: Outpatient, Health insurance, User Fees and logit model.

\section{Introduction}

The theoretical model for analyzing human capital, health, and its effect on productivity, earnings and labour supply was first developed in Grossman (1972). The premise of this theory is that an increase in a person's stock of health raises his or her productivity in both market and non-market activities. There exist large productivity and wages benefits of better health. There is evidence to show that sickness can have adverse effects on learning, and that these impacts can later influence economic outcomes in life (Bhargava et al., 2001). Better health can make workers more productive, either through fewer days off or through increased productivity while working. Improved nutrition and reduced disease, particularly in early childhood, leads to improved cognitive development, enhancing the ability to learn. Healthy children also gain more from school because they have fewer days absent due to ill health.

While health is determined by many factors including medical care, food, housing conditions and exercising, it is accepted that medical care is one of the key determinants in health production function (McKeown, 1976). 
Santerre and Neun, (2010) argued that much as a firm uses various inputs, such as capital and labour to manufacture a product, an individual uses health care inputs to produce health. When other factors are held constant, an individual health status indicates the maximum amount of health that can be generated from the quantity of medical care consumed.

Considering the importance of medical care, both policymakers and researchers have directed much attention to the question of how broad access to health services can be ensured (Lindelow, 2005). Early policy and research initiatives focused on the need to improve physical access through an expansion of the network of health facilities. This consisted of improving health care delivery including health care professionals, equipments, and buildings. A growing literature on health care has, however, pointed out that supply is not sufficient and this means that providing maximum access to health care remains a challenge for governments in many low income countries.

In Rwanda, access to health care was identified as an important objective in formulating public policies since good health is recognized as a necessary condition to enjoy economic and social opportunities. The country has developed a health care setting open to all Rwandans and that is accessible to everyone regardless of socioeconomic status. For instance, in the Rwanda Economic Development and Poverty Reduction Strategy (EDPRS, 2008), access to health care is one of the strategies of eradicating poverty. The strategy's objective is to promote health care to the entire population, increasing geographical accessibility, increase the availability and affordability of drugs, and improve the quality of services. Increased accessibility to health care has several benefits particularly among the poor segments of the population (World Bank, 2001a). The Millennium Development Goals (MDGs) also recognize health as an essential ingredient in social and economic progress for any country. However, despite the improvement in access to health care through Community Based Health Insurance Schemes (CBHIs) and other insurance providers, it is not known why health care utilization has remained low in Rwanda.

To increase access to health services, the government of Rwanda initiated a number of health policies and other economic stimulus efforts some of them targeting supply-side of the market while other policies were aimed at increasing services utilization. The policies included Vision 2020, Economic Development and Poverty Reduction Strategy (EDPRS) 2008-2012, One-Cow-One-Family, Social Security Policy 2009 and Health Policy 2004 (Ministry of Health, 2009). These policies were meant to increase access to health services and hence improve ultimately the health status of the population. The reforms were also meant to strengthen the health care system and make it more accessible (MOH, 2005). Despite these reforms, less than two out of five sick people seek formal health care in Rwanda (NISR, 2011). The ineffectiveness of previous policies aiming at increasing health care 
utilization is due to their implementation without adequate evidence as to factors influencing health service utilization in Rwanda. The aim of this study is to examine the factors that influence demand for outpatient health care services in Rwanda.

Although economic theory offers potential factors that influence demand for health care, there is lack of quantitative assessment of their effects in Rwanda. Evidence on these factors is needed in implementing policies designed to improve health service utilization in the country. To my knowledge, there are no studies in Rwanda that have been done in recent years to determine factors influencing health care demand. The only available evidence on this is from studies by Jayaraman et al., (2008) and Shimeles (2010) which focused on maternal health care and on effects of CBHIs at the district level. In countries in which estimates of demand for health care exist, research results provide conflicting evidence to demand effects of price, income and insurance suggesting that more studies are needed.

Most studies on demand for health care have not addressed the problems of endogeneity (reverse causality) and heterogeneity (variation in the estimated effect size due to unobservables). Failure to address these problems leads to biased estimates (Rosenzweig and Schultz, 1982; Kabubo-Mariara et al., 2009; and Lawson, 2004). Hunt-McCool et al., (1994) pointed out that differences in data, model specification, and/or empirical methods can contribute to diversity the demand estimates and hinder clarity in health care financing policies. The paper addresses these estimation problems, providing rigorous evidence on outpatient health care demand determinants in Rwanda that policy-makers can use to improve health service utilization across all the regions of the country.

\section{Literature}

Health care service is demanded as an input into the production of health that is part of the individual's utility function together with other goods. Empirically, the analysis of health services examines their determinants based on the microeconomic theory of consumer behaviour. These determinants include factors related to individuals, household and community. Numerous studies have attempted to quantify how much health care people consume, the types of health care they use, and the factors underlying utilization of health care.

Several studies have documented the impact of insurance on demand for health care and found that the effect of insurance on utilization varies across the population, the level and type of coverage (see Buchmueller et al., 2005; Barros and Galdeano, 2008). The study by Hahn (1994) found that uninsured households had lower average rates of utilization compared to persons with private or Medicaid coverage. Those with Medicaid for the full year were found to have the highest rate of health care utilization while the uninsured persons were found to have the lowest mean utilization for all types of services. In a similar study, 
Barros and Galdeano (2008) estimated the effect of private health insurance coverage beyond a National Health System on the demand for several health services in Portugal. The study estimated the impact of having additional coverage on the demand for 3 different health services; the number of visits, number of blood and urine tests, and the probability of visiting a dentist. The results showed large positive effects of coverage for the number of visits and tests.

Similar findings are reported by Jones et al., (2006) who found private insurance to be positively associated with the probability of health visits in Ireland, Italy, Portugal, Spain and the United Kingdom. Moreira and Barros (2009) reported comparable results of the impact of double health insurance coverage on demand for health services. Results show that double insurance increases utilization of health care. Another study by Shimeles (2010) examined the effects of a CBHI on health care utilization at district level in Rwanda. The study used the matching estimator to address the endogenity problem. As in Hahn (1994), higher utilization of health care services was reported among the insured than in uninsured households. The results indicate that $\mathrm{CBHI}$ has a strong positive impact on access to health care. The results were consistent with the findings by Newhouse, 1981; Saksena et al., 2010; Rashad and Markowitz, 2009; Jutting, 2005 which found that insurance was an important factor in explaining health seeking behavior.

Other studies however found that insurance may have little effect on demand for health care depending on geographical locations (Buchmueller et al., 2005). Cunningham and Kemper (1998) documented that in areas where there exist a well-functioning health care system, the lack or reduction of insurance coverage may not imply a significant lack of access to care. The expansion of coverage would then result in smaller changes in utilization than in locations where the uninsured have fewer options. For instance, Mwabu et al., (2003) reported a negative effect of insurance suggesting that insured people make fewer visits to health facilities relative to uninsured people. The reason for this unlikely result was that people with insurance may have better health endowments and, thus, demand fewer health care relative to uninsured people. However, none of the studies controlled for heterogeneity of insurance. Since the effect of insurance on utilization may vary across population, geographical location, the level and type of insurance coverage, health care demand research needs to handle the problem of heterogeneities to produce reliable estimates.

There is an extensive literature in health economics that sought to estimate the elasticity of income on demand for health services. Most of the literature show that demand for medical care was income inelastic indicating that medical care was a necessity good (Mocan et al., 2004). The positive sign of the elasticity indicates that as income increases, demand for health services also increases. However, the literature was inconclusive but noted that income effects vary widely across studies, 
countries and regions. Ringel et al., (2002) reports that income elasticity of demand using cross-section data ranges between 0 to 0.2 .

This kind of magnitude suggests however that the effect of income on demand is relatively small. The difference in estimates across time frames relies on the inclusion of the effects of changes in medical technology that use long time series data (Ringel et al., 2002). Income elasticities based on cross-sectional data or on time series data covering a relatively short period assumes that the level of available medical technology is constant. As real income in the population increases, the aggregate demand for new medical technologies and new treatment approaches rises as well. Thus, from the previous studies on the effect of income, no consensus has emerged, and the debate on whether health care is a luxury or necessity good continues (Blomqvist and Carter, 1997).

To account for the price effect at different levels of visits rather than the average effect obtained using Ordinary Least of Squares (OLS), Mwabu et al., (2003) used quantile regression method to analyze the effects of price on demand for health services in Kenya. The fees were found to have a negative effect on demand for health care but differing across the quantiles. The findings established that an increase of 10 shillings reduced visits by 0.2 percent. Clearly, the price elasticity of demand for medical care was found to be small in magnitude and consistent with Akin et al., (1986) and Sauerborn et al., (1994). The study did not however address the endogeneity and heterogeneity problems to produce unbiased estimates.

Given that demand for treatment is not determined by the individual alone, several studies have investigated the household and community factors. Lépine and Nestour (2008) controlling for the unobserved effects at the household and community level that affect health seeking behavior show that household economic status and quality of health care are important determinants of the probability of seeking treatment from a qualified provider. In addition, transportation cost was found to be an important determinant of the likelihood of seeking care as an increase of the average transport cost decreased the likelihood to seek curative care by 25 percent.

Evidence from empirical studies on the relationship between demand for health care and its main determinants differed in several ways. In addition, most of previous studies assumed an exogenous insurance and did not consider the reverse causality that is more likely to exist between medical care demand and health insurance. This study provides new evidence on the factors which affect demand for health care using data from Rwanda and handles the endogeneity and heterogeneity problems to ensure that estimates are unbiased and consistent. 


\section{Methodology}

Following Grossman's (1972a and b), individuals maximize their utility over health and other goods subject to market and non-market factors. Health is one of the several commodities over which individuals have well-defined preferences. The market factors include availability of health inputs and their prices, insurance and household income. The nonmarket factors include household characteristics, location or distance and individual characteristics such as age, education, health status, and the perception they have about the quality of health services (Appleton and Song, 1999; Ajakaiye and Mwabu, 2007; Bategeka, 2009). Assuming that health care is a consumption good, the consumer's problem can be expressed as:

$$
\operatorname{Max} U=U(H, Z, X, Y)
$$

where $\mathrm{U}$ is the utility derived from consumption of different goods; $\mathrm{Y}$ is the health related goods that yield utility to the sick person and improve health status; $\mathrm{H}$ is the health production function; $\mathrm{Z}$ stands for health inputs such as health care while $\mathrm{X}$ represents all other goods and services.

The utility function is maximized subject to the following constraints:

$$
\begin{aligned}
& B=X P_{x}+Y P_{y}+Z P_{z} \\
& H=H\left(Z, I, S, C, A, h_{s}, P_{h}, N_{O}\right)
\end{aligned}
$$

Where $\mathrm{Z}$ is defined as in equation (1) and I is household characteristics including insurance; $\mathrm{S}$ is the socio-demographic variables including age, sex and education; $\mathrm{C}$ stands for community characteristics including distance to health facility; $A$ is the household asset; $h_{s}$ is the size of the household; $\mathrm{P}_{\mathrm{h}}$ is the price of health while $\mathrm{N}_{\mathrm{o}}$ is the household nonobservable characteristics. In the first constraint, $\mathrm{B}$ is the exogenous income and $\mathrm{P}_{\mathrm{x}}, \mathrm{P}_{\mathrm{y}}$ and $\mathrm{P}_{\mathrm{z}}$ are, respectively, the prices of health neutral goods (such as clothing), health related consumer good $\mathrm{Z}$ (such as health care) and health investment good $\mathrm{Y}$ such as exercising.

The maximization problem is then expressed as:

$$
\begin{aligned}
& \operatorname{Max} U=U(H, Z, X, Y) \\
& \text { Given } H=H\left(Z, I, S, C, A, h_{s}, P_{h}, N_{O}\right)
\end{aligned}
$$

s.t.

$$
\left.B=X P_{x}+Y P_{y}+Z P_{z}\right)
$$

Solving the maximization problem yields a demand function for health care specified as:

$$
D_{h}=f\left(I, B, A, S, C, h_{s}, P_{h}, N_{o}\right)
$$


Where $D_{h}$ refers to the demand for outpatient; I is health insurance; $B$ is the budget or income; A stands for household asset and $\mathrm{S}$ stands for socio-demographic variables. $\mathrm{C}$ represents the community characteristics including distance to health facility; $\mathrm{h}_{\mathrm{s}}$ is the household composition; $\mathrm{P}_{\mathrm{h}}$ is the price of health care and $\mathrm{N}_{0}$ is the household non-observable characteristics.

Equation (5) is a structural outpatient health care demand equation that includes an endogenous variable among the independent variables. The endogenous variable is health insurance because of reverse causality between demand for health care and insurance while exogenous variables include monetary prices for health care, income, age, gender, educational attainment of the individual, household size, location as well as regions. In this study, the demand for outpatient care is discrete rather than continuous because patients seek or do not seek health care. In equations (1) and (2), health investment good is purchased only for the purpose of improving health so that it enters an individual's utility function only through $H$.

In the demand for outpatient model, insurance is assumed to improve access to health services. In addition, the heterogeneity of health insurance due to non-linear interaction of demand for health services with unobservable and omitted variables could bias the estimates. The study assumes that demand for health services has only one endogenous variable. In this study, demand for outpatient refers to any curative outpatient service provided by a physician or any other medical staff. Given the dichotomous nature of the outpatient, the estimation adopts a binary discrete model, where health care is either sought or not. Assuming that the errors are distributed logistically, we adopt a Logit regression method to estimate both outpatient and inpatient health care demands. The dependent variable takes any two values; 1 if individual uses outpatient health care and 0 representing the individuals who did not use any health services. The logit regression is also preferred because most of the studies in demand for health services use logit regression (See Lépine and Nestour, 2008 and Hahn, 1994). This relationship can be expressed as:

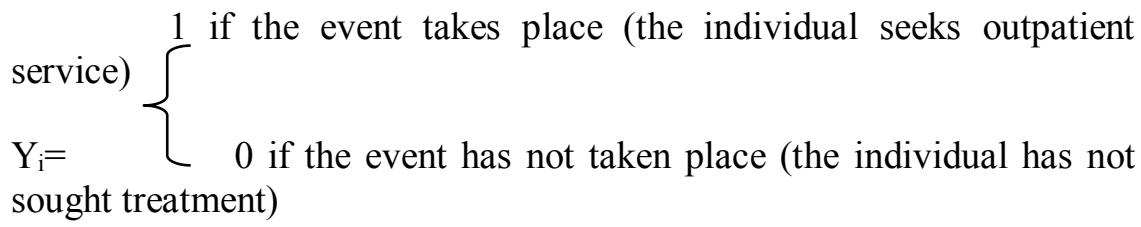

Equation (5) expressing the demand for health care can be rewritten as:

$$
y^{*}{ }_{i}=x_{i}{ }^{\prime} \beta+\varepsilon_{i}
$$

where $y^{*}{ }_{i}$ is a latent variable showing the probability that medical care is or not sought, $\boldsymbol{x}_{\boldsymbol{i}}{ }^{\prime}$ is a vector of characteristics related to the individual, household and community, and $\varepsilon_{i}$ is the error term. 


$$
\begin{aligned}
& \mathrm{Y}=1 \text { if } y^{*}{ }_{i}>0 \text { i.e. }\left(x_{i}{ }^{\prime} \beta+\varepsilon_{i}\right)>0 \\
& \text { and } \mathrm{Y}=0 \text { if } y^{*}{ }_{i}<0 \text { i.e. }\left(x_{i}{ }^{\prime} \beta+\varepsilon_{i}\right)<0
\end{aligned}
$$

The values 0 and 1 are used because they allow the definition of probability of occurrence of an event as the mathematical expectation of the variable $\mathrm{Y}$. This can be expressed as:

$$
E\left[Y_{i}\right]=\operatorname{Pr}\left(Y_{i}=1\right) * 1+\operatorname{Pr}\left(Y_{i}\right) * 0=\operatorname{Pr}\left(Y_{i}=1\right)=\pi_{i}
$$

This equation shows that we need to compute the probability of occurrence $(\mathrm{Y}=1)$ over the probability of no-occurrence $(\mathrm{Y}=0)$. Assuming that the error term has an extreme value distribution, this can be done using the logit relation as shown by equation 8 .

$\operatorname{Pr}\left(\mathrm{Y}_{\mathrm{i}}=1\right)=\frac{\exp \left(\beta_{0}+\beta_{1} X_{1 i}+\beta_{2} X_{2 i}+\ldots+\beta_{k} X_{k i}\right)}{1+\exp \left(\beta_{0}+\beta_{1} X_{1 i}+\beta_{2} X_{2 i}+\ldots+\beta_{k} X_{k i}\right)}$

In terms of the log-odds, the above expression can be reformulated as

$$
\begin{aligned}
& \ln \left[\frac{\operatorname{Pr}\left(Y_{i}=1\right)}{1-\operatorname{Pr}\left(Y_{i}=1\right)}\right]=\ln \left[\frac{\operatorname{Pr}\left(Y_{i}=1\right)}{\operatorname{Pr}\left(Y_{i}=0\right)}\right]=\ln \left[\frac{\pi_{i}}{1-\pi_{i}}\right] \\
= & \beta_{0}+\sum_{j=1}^{k} \beta_{j} X_{j i}=\log i t\left(\pi_{i}\right)
\end{aligned}
$$

Which is can be expressed as:

$$
\log i t\left(\pi_{i}\right)=\beta_{0}+\sum_{j=1}^{3} \beta_{j} X_{j i}=\beta_{0}+\beta_{1} X_{1 i}+\beta_{2} X_{2 i}+\beta_{3} X_{3 i}+\varepsilon_{i}
$$

Where $Y_{i}$ is an indicator for the choice of modern health care (outpatient) by the $\mathrm{i}^{\text {th }}$ household member,

$\mathrm{X}_{1 \mathrm{i}}=$ Vector of characteristics related to individuals like age, education and sex,

$\mathrm{X}_{2 \mathrm{i}}=$ Vector of characteristics related to household such as income, insurance,

$\mathrm{X}_{3 \mathrm{i}}=$ Vector of characteristics related to community level characteristics such as medical specialist, and the distance from household to health facility.

If in equation (10) $\beta_{j}>0$, then an increase in $\mathrm{X}_{\mathrm{ji}}$ (for instance the household income), while all other exogenous variables remain unchanged will increase the log-odds ratio of individual i seeking health services. If $\beta_{j}<0$, then an increase in $\mathrm{X}_{\mathrm{ji}}$ (for example the user fee), will reduce the $\log$-odds ratio. If $\beta_{j}=0$, then the variable has no effect.

However, in the case of expression (10), the $\beta$ s indicate the changes in logistic index with the sign of $\beta$ indicating the direction of the eventual change in the probability of seeking care from a given health facility. Equation (10) is the structural form of the probabilistic health care 
demand function. In this equation as in the recent literature, one of the independent variables, health insurance is endogenous and the estimation has to address this problem. Endogeneity is due to the reverse causality between health insurance and demand for health care. So, in order to obtain unbiased and consistent estimates, instrumentation of the endogenous variable is required. The instrumental variable should be correlated with the endogenous regressor but unrelated directly to the dependent variable (Ajakaiye and Mwabu, 2007).

Health insurance in equations (10) is endogenous to the dependent variable. Thus, estimating the equations without taking into account this problem might encounter the problem of simultaneity which is due to the possibility of reverse causality between demand functions and health insurance. Endogeneity of health insurance arises because the decision to purchase health insurance and the utilization of health services are intertwined. First, since insurance reduces the effective price of medical care, insured people tend to consume more health services (Rashad and Markowitz, 2009). Second, even if individuals cannot perfectly predict their future health needs, they are likely to have information about their health status that could lead them to anticipate higher use of health services, and then decide to buy health insurance.

Thus, health care utilization not only depends on the individual's health insurance coverage, but also the level of coverage may be influenced by anticipated utilization of health services (Jutting, 2004). Manning et al., (1987) argue that treating insurance as exogenous in demand for health care models produces biased results. This is because people who anticipate consuming more health services have an obvious incentive to obtain insurance cover either by selecting a more generous option at the place of employment by working for an employer with a generous insurance plan, or by purchasing privately a generous coverage.

Existing literature suggests useful methods for dealing with the endogeneity problem. Among the common approaches to this problem is the use of Two Stages Residuals Inclusion (2SRI) regression method which is appropriate for non-linear models. The procedure is used to address the problems relating to measurement error, simultaneity and omitted variables. This method requires identification an observable variable or instrument that is correlated with the endogenous variable but uncorrelated with the error-term (Kioko, 2008; Ajakaiye and Mwabu, 2007; Rosenzweig and Schultz, 1982; Strauss and Thomas, 1995; and Wooldridge, 2002). The problem however, is to identify an observable variable, $\mathrm{z}_{\mathrm{i}}$, that satisfies two conditions. First, the selected variable is uncorrelated with the error-term. This means that $\operatorname{cov}\left(\mathrm{z}_{\mathrm{i}}, \varepsilon\right)=0$, that is, $\mathrm{Z}_{\mathrm{i}}$ is exogenous in the estimation of the endogenous equation (see Wooldridge, 2002; Behrman and Deolalikar, 1988; Griliches and Mairess, 1998; and Ackerberg and Caves, 2003).

The second requirement involves the relationship between the identified instrument, zi, and demand for health services. This means that the 
identified variable should not have an impact on health insurance; i.e., $\mathrm{z}_{\mathrm{i}}$ must be relevant. This requires regressing health insurance against all the exogenous variables, including the instrument (Wooldridge, 2002; Greene, 2007; Jowett et al., 2004). In the first regression, the variables should have significant coefficients when the choice variable is regressed on the identifying variable together with all other exogenous variables (Ackerberg and Caves, 2003; Baum and Schaffer, 2003). In the first stage, we estimated the reduced-form of health insurance on all exogenous variables including the instrumental variables. The second stage regressed demand for health care on all independent variables plus insurance and insurance residuals obtained from the first stage regression (Terza et al., 2008 and Palmer et al., 2008).

Following Ajakaiye and Mwabu (2007); Mwabu (2008); KabuboMariara et al., 2009 and Bhasin and Bentum, (2010), we can re-formulate the demand for health services in the form of simultaneous equation as:

$$
\begin{aligned}
& D=\delta_{d} Z_{1}+\beta_{j} I_{j}+\varepsilon_{i j}, \mathrm{j}=1 \ldots 2 \\
& I=\delta_{j} Z+\varepsilon_{2}
\end{aligned}
$$

where $\mathrm{D}$ and $\mathrm{I}$ are demand for health care and health insurance respectively. $\mathrm{Z}$ is a vector of independent variables, consisting of $\mathrm{Z}_{1}$ covariates that belong to the demand for health services function and a vector of instrumental variables that affect insurance but have no direct impact on demand for health services. $\delta$ and $\beta$ are parameters to be estimated and $\mathcal{E}$ is a disturbance term. Equation (11) is the structural equation to be estimated while equation (12) is the linear projection of the potentially endogenous variable $I$, on all the exogenous variables. The system of equations assumes that there is only one endogenous regressor in the demand equation.

The major challenge of the instrumental variable approach is the challenge of obtaining valid instrument for identifying the effect of endogenous variables in a structural model. Once potential instrument is identified, it is important to test for its suitability by assessing whether it has three properties: relevance, strength and exogeneity of instruments (Stock, 2010; Kabubo-Mariara et al., 2009). An instrument satisfying all three properties is said to be strong and valid instrument. As used in Meer and Harvey (2004), after testing for validity and strength, the variables employment status and community health association membership were used as instrument for insurance.

We tested for the endogeneity of insurance and the validity of instruments. First, we carried out the test for endogeneity of health insurance. If insurance is exogenous, there would be no justification to estimate the structural model of demand for health care, because the logit models would yield unbiased estimates. We used the Durbin-WuHausman test. The results showed that the Durbin-Wu-Hausman statistic values were significant at the 10 percent level.

86 Rwanda Journal Series B: Social Sciences, Volume 3, 2016 
We also conducted the Wald test of exogeneity of the insurance variable which showed that the values were significant at the 1 percent level. We then rejected the null hypothesis of exogenous insurance. Second, the coefficients of insurance residuals variable were also significant at the 1 percent level to the demand for medical care services. Third, we tested the impact of the instruments on the dependent variable. These were found to be insignificant. Fourth, the strength of the instruments was tested by considering the impact of the instruments on endogenous variable. As the coefficients on instruments were large and significant at the 1 percent level, the instruments were strong. In addition, we conducted the F-test to check the role of the instruments on the endogenous variable. While an F-statistic of at least 10 is recommended (Kioko, 2008; Staiger and Stock, 1997), the minimum Eigen value statistic for F-test was 133.04 suggesting that the null hypothesis of weak instrument had to be rejected.

A second estimation issue is the heterogeneity bias which arises from unobserved factors interacting with the variable of interest and thus biasing the results. These are some unobservable preferences and health endowments of individuals that influence their demand for health care (Schultz, 2008; Kabubo-Mariara et al., 2009). Even with valid instruments, it is not easy in practice to separate the impact of endogenous variable from the effect of unobservables in a structural model. Failure to take into account heterogeneity could lead to unreliable estimates.

In this study, heterogeneity may arise from at least three sources. First, a risk reduction effect; where the preferred level of utilization is greater because of the financial certainty created by insurance than under uncertainty (Meza, 1983). Second, an access effect; where the insurance may extend an individual's opportunity set by giving access to health care that would not otherwise be available to them. Nyman (1999) argued that the pooling effect of insurance provides access to expensive medical technologies that would not be affordable. Third, an income transfer effect where insurance creates an ex-post transfer of income from the healthy to the ill and this may increase utilization through an income effect on the demand for medical care (Nyman, 1999). The three sources relate to reasons known by the individual but not by the researcher from which health insurance may affect demand for health services.

To handle the problem of heterogeneity, we used the Control Function approach (CFA) (Florens et al., 2008). This involved estimating a reduced form insurance residual $\left(\mathrm{I}^{*}\right)$ where the inclusion of the residuals is identical to the one obtained by 2SRI using an instrument for insurance. Assuming the unobserved component is linear in the insurance residual (I*), we introduced an interaction term (of the insurance and its residual (II*)) as a second control variable to eliminate endogeneity bias 
even if in the case where the reduced form insurance is heteroscedastic (Card, 2001).

Introducing the control function variables (insurance residual and interaction) yields equation (13).

$D=\beta_{0}+\delta_{d} Z_{1}+\tau I^{*}+\gamma I I^{*}+\varepsilon_{1}$

Where I* is the fitted residuals from the reduced form of the insurance variable, which is explained by $Z_{1}$; all other variables are as defined earlier. $\tau I^{*}$ captures the non-linear indirect effects of insurance (I) on demand for health services (D), because the fitted residuals serve as a control for unobservable variables which are correlated with insurance. Inclusion of both $\mathrm{I}^{*}$ and the interaction term II* control for the effects of unobservable factors and therefore purge the coefficients of the structural equation of the effects of the unobservables (Card 2001, Ajakaiye and Mwabu 2007). If any unobservable variable is linear in I*, it is only the intercept in equation (27) that is affected by the unobservables and therefore the 2SRI estimates are efficient without the interaction term (II*). The 2SRI estimates will be unbiased and consistent if at least one of two conditions holds: First, the expected value of the interaction between insurance and its fitted residuals is zero. Second, the expectation of the interaction between insurance and the fitted residuals is linear (Wooldridge, 1997).

The data used in this paper is drawn from the Integrated Household Living Conditions survey (EICV2) conducted in 2005 by the National Institute of Statistics of Rwanda (NISR). This nationally representative survey collected data from 7,620 households and 34,819 individuals. Data was collected at the household and the individual level. The EICV2 aimed at enabling the government to assess the impact of the different implemented policies and programs in improving the living conditions of the population in general.

The survey covered all the 30 districts in Rwanda and collected data on a wide spectrum of socioeconomic indicators, labour, housing, health, agriculture, debt, livestock, expenditure and consumption in different areas, regions and locations of the country. Household level information included consumption expenditures on health, OOPE (consultation; laboratory tests; hospitalization; and medication costs). Individual level information included socio-economic indicators and insurance status. There were also a number of community variables such as distance to the nearest health facility. To improve reliability of data, the recall period for the use of health services was 2 weeks prior to the survey. In this paper, demand for health care services was estimated for a single visit because the survey did not capture multi-visits to health facilities. Hence, the demand for outpatient is limited to the last consultation or admission.

\section{Results and discussion}

In Table 1, the Wald chi2 tests measuring the goodness of fit indicate that the estimated models give an adequate description of the data 
because it is highly significant implying that all models parameters are jointly different from zero. The 2SRI results are reported in columns (45 ) of Table 1 while the first stage regression estimates are given in Table A2 in the Appendix. Table 1 in columns 6-7 presents results of demand for outpatient care after correcting for heterogeneity of insurance. Due to the inclusion of insurance residuals and interaction of insurance residuals and insurance, the results remain close to the 2SRI results in terms of signs of coefficients although different in magnitudes.

The significance of the coefficient on insurance residuals suggests that insurance is endogenous to outpatient medical demand care. The coefficient on the interaction of the insurance residuals and insurance is significant at the 1 percent level indicating the presence of heterogeneity arising from interaction of insurance with unobserved determinants of demand for outpatient. For comparison purpose, the baseline model (logit) estimates are also presented in columns (2-3). They appear to be weaker than 2SRI results since the coefficient on health insurance increases from 0.49 to 0.9 across model specifications (moving from logit to 2SRI) while the z-value remains statistically significant. This shows that treating insurance as exogenous highly understates its impact on demand for outpatient medical care.

On average higher user fees reduce the probability of using outpatient health services. This finding is similar to the results reported by Litvack and Bodart (1993); Ridde (2003); Diop et al., (1995) and Manji et al (1992) who report negative effects of user fees on health service uptake. In particular, Manji et al., (1992) showed that uptake of treatment in Kenyan schools fell from 75 percent to 19 percent after fees were introduced. This suggested that the introduction of cost-sharing was responsible for the major part of the reduction in uptake. Similarly, De Bethune et al., (1989) and Yoder, (1989) found the price of health care to be a significant hindrance to demand for medical services in Swaziland. However, this study has confirmed the results by other cross-section studies that demand for health care is inelastic to price. Oxaal and Cook (1998) showed that that the relationship between price and health is inelastic because of failure to disaggregate its effect from the one of income.

The coefficients on education indicate positive association with demand for outpatient health services in Rwanda. The result is consistent with the work of Katz et al., (2001), which showed that, the more individuals get educated, the more they come into contact with other educated individuals who have a high demand for health care. The social interaction which begins during schooling years continues into the workplace leads to adoption of health-improving behaviours, including health service utilization. The evidence from Rwanda is also in line with Elo (1992) and Blunch (2004) who observed a strong positive association between education and the use of health services. 
Insurance is found to be an important determinant of demand for outpatient medical services in Rwanda. Insurance reduces the price of health care which makes the service more affordable than without insurance. The result on insurance finds support in findings from previous studies which addressed the endogeneity problem when estimating demand effect of insurance (see e.g. Rashad and Markowitz, 2009; Shimeles, 2010; Meer and Harvey, 2004). Similar results were reported by Phelps and Newhouse (1974) who used data on co-insurance plans in the United States, Canada and the United Kingdom. The results were such that the level of sensitivity of demand depended on the coinsurance rate.

The evidence presented in the paper reveals that gender is an important factor affecting the use of outpatient health services in Rwanda where females were more likely to use outpatient services as compared to men. The results are in line with those reported by Miller (1994) who argued that females demand more health care than males because of their role in childbearing. Miller (1994) added that some illnesses, such as cardiovascular disease, osteoporosis, immunologic diseases, and Alzheimer's disease are more prevalent in women than men. In line with this, Ahmad (2001) added that the gender differences in health care utilization for women were related to specific diseases such as cardiovascular and chronic illnesses.

Some research has shown that women use less outpatient health care than men because of the time they spend taking care of the elderly and other people with disabilities. Caregivers, especially women elderly caregivers were found to neglect their own health in order to fulfill this responsibility (Fredman et al., 2008). These responsibilities made it difficult for severely disadvantaged women to take steps to improve their living situations and health behaviors by consuming less health services than men. Similarly, Oxaal and Cook (1998) showed that the constraints to access for poor women and girls made them less likely to have access to appropriate care and to seek adequate treatment. Their paper noted that the range of factors limiting access for women included socio-economic status of households; time constraints; composition of households; intrahousehold resource allocation and decision-making, less of education and employment; and legal or social constraints on access to care, heavy work burdens and the opportunity costs of time in seeking care.

Given the above results, a number of recommendations emerge. Since user fees are an impediment to using health care in Rwanda, the government should reduce user fees at health facilities through increased budget allocations to all health facilities, particularly in the public sector, where the poor go for medical care. From 2003, OOPE gradually increased to reach 32.2 percent of the total health expenditures in 2010. High OOPE have a variety of negative consequences, including household impoverishment. The subsidies on user fees should target the vulnerable groups, such as children and women or low income 
households. The government should also consider subsidizing private health facilities to increase access to their high quality services by low income households. The subsidies would help to reduce the effect of income inequalities in health care utilization.

Health insurance is an important determinant of health care seeking behaviour in Rwanda. Thus, policies that increase health insurance coverage would substantially increase health service utilization. The 2013 health insurance coverage rate in Rwanda is 73 percent, the highest in East African Community, but the high premiums associated with this coverage are not sustainable. The government should subsidize health insurance to make it accessible to the most disadvantaged people. The current level of premium of $\$ 4.5$ for CBHIs per year and per person should be reduced. The premium rate more than doubled in 2011, from $\$$ 1.7 to $\$ 4.5$, and this reduced the coverage rate from 91 percent to 73 percent. In addition, while with the earlier premium level, health care expenditure represented 10 percent of the total household expenditure, holding other factors constant, with the new premium, the health care expenditure for household would represent 26 percent of the household health expenditure. This would cause households to incur catastrophic expenditures and push them into poverty. Further, with an average household size of 6.6 persons per household, this level of premium per individual does not seem to be sustainable given that 44.9 percent of the population lives with less than $\$ 1$ per day.

Table 2: Logistic Demand Estimates for Outpatient Care: Dependent variable is probability of an outpatient visit

\begin{tabular}{|l|l|l|l|l|l|l|}
\hline $\begin{array}{l}\text { Explanat } \\
\text { ory } \\
\text { variables }\end{array}$ & $\begin{array}{l}\text { Baseline } \\
\text { Estimates }\end{array}$ & $\begin{array}{l}\text { z- } \\
\text { statistics }\end{array}$ & $\begin{array}{l}\text { 2SRI } \\
\text { Estimates }\end{array}$ & $\begin{array}{l}\text { z- } \\
\text { statistics }\end{array}$ & $\begin{array}{l}\text { Control } \\
\text { Function } \\
\text { Estimates }\end{array}$ & $\begin{array}{l}\text { z- } \\
\text { statistics }\end{array}$ \\
\hline $\begin{array}{l}\text { Househol } \\
\text { d income }\end{array}$ & 0.00030 & $3.50^{* * *}$ & 0.0004 & $3.6^{* * *}$ & 0.003 & $3.40^{* * *}$ \\
\hline User fees & -1.108 & $-26.74^{* * *}$ & -0.98 & $-15.4^{* * *}$ & -1.43 & $-18.9^{* * *}$ \\
\hline $\begin{array}{l}\text { Quality } \\
\text { of health } \\
\text { care (=1) }\end{array}$ & -0.011 & -0.27 & -0.01 & -0.41 & -0.004 & -0.11 \\
\hline $\begin{array}{l}\text { Health } \\
\text { insurance } \\
(=1)\end{array}$ & 0.492 & $13.26^{* * *}$ & 0.921 & $1.87^{*}$ & 4.106 & $29.29^{* * *}$ \\
\hline $\begin{array}{l}\text { Distance } \\
\text { to the } \\
\text { health }\end{array}$ & -0.434 & $-8.00^{* * *}$ & -0.072 & $-5.2^{* * *}$ & -0.239 & $-4.29^{* * *}$ \\
\hline
\end{tabular}




\begin{tabular}{|c|c|c|c|c|c|c|}
\hline facility & & & & & & \\
\hline $\begin{array}{l}\text { Househol } \\
\text { d size }\end{array}$ & -0.019 & $-2.52 * *$ & 0.004 & $1.79^{*}$ & -0.017 & $-2.31 * *$ \\
\hline Age & 0.013 & $2.57 * *$ & 0.056 & $1.91^{*}$ & -0.0008 & -0.74 \\
\hline $\begin{array}{l}\text { Square } \\
\text { age }\end{array}$ & -0.001 & $-2.90 * *$ & -0.0051 & $-2.79 * *$ & -0.0002 & $--1.8^{*}$ \\
\hline $\begin{array}{l}\text { Primary } \\
(=1)\end{array}$ & 0.006 & $1.89 *$ & 0.021 & $3.2^{* *}$ & 0.018 & $2.4 * *$ \\
\hline $\begin{array}{l}\text { Secondar } \\
\mathrm{y}(=1)\end{array}$ & 0.03 & $2.9^{*}$ & 0.04 & $1.95^{*}$ & 0.028 & $1.99^{*}$ \\
\hline $\begin{array}{l}\text { Tertiary } \\
(=1)\end{array}$ & 0.002 & $5.8^{* * *}$ & 0.008 & $4.12^{* * *}$ & 0.067 & $2.02 * *$ \\
\hline $\begin{array}{l}\text { Male } \\
(=1)\end{array}$ & -0.163 & $-4.44 * * *$ & -0.023 & $-3.66 * * *$ & -0.148 & $-3.85 * * *$ \\
\hline $\begin{array}{l}\text { Urban } \\
(=1)\end{array}$ & -0.311 & $-4.19 * * *$ & -0.34 & $-5.15 * * *$ & -0.164 & $-2.14 * *$ \\
\hline $\begin{array}{l}\text { Kigali } \\
\text { region } \\
(=1)\end{array}$ & -0.035 & -0.45 & -0.07 & -1.43 & -0.024 & -0.26 \\
\hline $\begin{array}{l}\text { Southern } \\
\text { region } \\
(=1)\end{array}$ & -0.066 & 1.23 & -0.204 & $-2.67 * *$ & -0.063 & -1.18 \\
\hline $\begin{array}{l}\text { Western } \\
\text { region } \\
(=1)\end{array}$ & 0.027 & 0.53 & 0.024 & $2.4^{* *}$ & 0.035 & 0.68 \\
\hline $\begin{array}{l}\text { Northern } \\
\text { region } \\
(=1)\end{array}$ & 0.195 & $3.25^{* * *}$ & 0.17 & $3.54 * * *$ & 0.164 & $2.73 * *$ \\
\hline $\begin{array}{l}\text { Insurance } \\
\text { residuals }\end{array}$ & - & - & -1.3 & $-4.7 * * *$ & -2.869 & $19.05 * * *$ \\
\hline $\begin{array}{l}\text { Interactio } \\
\mathrm{n} \quad \text { of } \\
\text { insurance } \\
\text { and } \\
\text { insurance } \\
\text { residuals }\end{array}$ & - & - & - & - & -1.269 & $-6.88 * * *$ \\
\hline
\end{tabular}




\begin{tabular}{|c|c|c|c|c|c|c|}
\hline Constant & -2.644 & -24.56 & -1.789 & -5.67 & -2.411 & -25.62 \\
\hline \multicolumn{3}{|c|}{$\begin{array}{l}\text { Number of observations }= \\
5040\end{array}$} & \multicolumn{2}{|l|}{5040} & \multicolumn{2}{|r|}{5040} \\
\hline \multicolumn{3}{|c|}{ Durbin-Wu-Hausman chi-sq } & \multicolumn{2}{|l|}{$0.054^{*}$} & & \\
\hline \multicolumn{3}{|l|}{$\mathrm{F}(1,5040)$} & \multicolumn{2}{|l|}{133.88} & & \\
\hline \multicolumn{3}{|c|}{$\begin{array}{ll}\mathrm{LR} & \operatorname{chi} 2(19) \\
5880.20 * * * & \end{array}$} & \multicolumn{2}{|c|}{$5889.70^{* * * *}$} & \multicolumn{2}{|c|}{$5897.44 * * *$} \\
\hline \multicolumn{2}{|c|}{$\begin{array}{l}\log \\
-3020.4388\end{array}$} & Likelihood & \multicolumn{2}{|c|}{-3016.3138} & \multicolumn{2}{|c|}{-3006.2254} \\
\hline
\end{tabular}

Note: $* * *, * *$ and $*=$ significant at $1 \%, 5 \%$ and $10 \%$ level respectively

Source: Researcher's own construction

\section{REFERENCES}

1. Ackerberg D. A. and K. Caves (2003). Structural Identification of Production Functions: An Application to the Timing of Input Choice. Department of Economics, UCLA, Los Angeles, CA 90095.

2. American Hospital Association (2001). Guidelines for the Evaluation and Management of Chronic Heart Failure in the Adult. International Society for Heart and Lung Transplantation, Volume 3, Number 3.

3. Ahmad F. (2001). Rural physicians perspectives on cervical and breast cancer screening: a Gender-based analysis. J Women's Health Gender-Based Med 5, 2: pp. 201.08.

4. Ajakaiye O. and G. Mwabu (2007). The Demand for reproductive health services: An Application of Control function Approach. AERC, Nairobi.

5. Akin J. S., D. K. Griffin and B.M. Popkin (1986). The Demand for Primary Health services in The Bicol Region of the Philippines. Economic development and Cultural Change, 34(4):755-782.

6. Appleton S. and L. Song (1999). Income and Human Development at the Household level, Evidence from six countries. Oxford University, Mimeo.

7. Barros P. and P. Machado (2007). Moral hazard and the demand for health services: a Matching estimator approach. JEL, C31, 111.

8. Bategeka L. O., L. Asekeny and J. A. Musiime (2009). The Determinants of Birth weight in Uganda. AERC, Nairobi.

9. Bhargava A., D. Jamison, L. Lau and C. Murray (2001). Modeling the effects of Health on Economic Growth. Journal of Health Economics 20: 423-40. 
10. Behrman J.R. and A.B. Deolalikar (1988). Health and Nutrition. Handbook of Development Economics. Chenery H. and Srinivasan T.N. North Holland, Elsevier Science Publishers BV.

11. Bhasin V. K., C. Obeng and Bentum-Ennin (2010). Fertility, Income and Household Poverty in Ghana. Journal of Business and Policy Research, Volume 5. Number 2.

12. Blomqvist A. G. and R. A. L. Carter (1997). Is health care really a luxury? Journal of Health Economics, 16(2), 207-229.

13. Bloom D and D. Canning (2004). The Effect of Health on Economic Growth: A Production Function Approach, World Development V 32, No 1.

14. Blunch N. (2004). Maternal Literacy and Numeracy Skills and Child Health in Ghana. A paper presented at the Northeast Universities Development Consortium Conference, HEC Montreal, October 1-3.

15. Bound J., D. Jaeger and R. Baker (1995). Problems with Instrumental Variables Estimation when the Correlation between Instruments and the Endogenous Explanatory Variables is Weak. Journal of the American Statistical Association, 90(430): 443 450.

16. Buchmueller T. C., K. Grumbach, R. Kronick and J. G. Kahn (2005). The Effect of Health Insurance on Medical Care Utilization and Implications for Insurance Expansion: A Review of the Literature, Medical Care Research and Review, Vol. 62 No. 1.

17. Card D. (2001). Estimating the Return to Schooling: Progress on Some Persistent Econometric Problems. Econometrica, 69(5):1127-60.

18. Cunningham P. and P. Kemper (1998). Ability to obtain medical care for the uninsured: How much does it vary across communities? JAMA 280 (10): 921-27.

19. De Bethune, X., S. Alfani, and J. P. Lahaye (1989). The influence of an abrupt price increase on Health service utilization: evidence from Zaire. Health Policy and Planning, 4(1), 76-81.

20. Diop F., A. Yazbeck and R. Bitrán (1995).The impact of alternative cost recovery schemes on access and equity in Niger. Health Policy Plan, 10: 223-40.

21. Elo I. (1992). Utilization of Maternal Health-care Services in Peru; The Role of Women's Education. Population Studies Center, University of Pennisylvania, PA 19104.

22. Florens J.P., M. C. Heckman and E. Vytlacil (2008). Identification of Treatment Effects Using Control Functions in Models with Continuous, Endogenous Treatment and Heterogeneous Effects. Econometrica, 76(5)1191-1206.

23. Fredman L, J.A. Cauley and S. Satterfield (2008). Caregiving, mortality, and mobility decline: The Health, Aging, and Body 
Composition (Health ABC) Study. Arch Intern Med; 168:21542162.

24. Griliches Z. and J. Mairesse (1995). Production Functions: The Search for Identification. National Bureau of Economic Research, Working Paper No.5067.

25. Greene W.L. (2007). Econometric Analysis. New York. Macmillan Publishing Company.

26. Grossman M. (1972a). On the Concept of Health Capital and the Demand for Health. Journal of Political Economy, 80 (2): 223235.

27. Grossman M. (1972b). The Demand for Health: A Theoretical and Empirical Investigation. NBER and Columbia University Press, New York.

28. Hahn B. (1994). Health Care Utilization: The Effect of Extending Insurance to Adults on Medicaid or Uninsured. MEDICAL CARE, Volume 32, Number 3, pp 227-239.

29. Hong R. M. Ayad, S. Rutstein, and R. Ren (2009). Childhood mortality in Rwanda: levels, trends, and differentials. Further analysis of the Rwanda Demographic and Health Surveys. 1992_2007/08. USAID. Calveton, Maryland, USA.

30. Hunt-McCool J., B. F. Kiker and Y. C. Ng, (1994). Estimates of the Demand for Medical Care Under Different Functional Forms. Journal of Applied Econometrics, Vol. 9, No. 2.

31. Janssen R. (1992). Time prices and the demand for GP services. Social Sciences and Medicine 34(7):725-733.

32. Jayaraman A. S. Chadndrasekhar and T. Gebreselassie (2008). Factors affecting maternal healthcare seeking in Rwanda. USAID. Working Paper.Jones A. M., X. Koolman and E. V. Doorslaer (2006). The impact of Having Supplementary. Private Health Insurance on the Use of Specialists in European Countries. Anales d'Economie et de Statistique. No.83/84, 25175.

33. Jowett M., A. Deolalikar and P. Martinsson (2004). Health insurance and treatment seeking behaviour: evidence from a lowincome country. Health Economics, 13: 845-857.

34. Jütting J. P. (2004). Do Community-Based Health Insurance Schemes Improve Poor People's Access to Health Care? Evidence from Rural Senegal. World Development, 32:273-288.

35. Kabubo-Mariara J. D. Mwabu and G.K. Nd'enge (2009). The Consequences of Fertility for Child Health in Kenya: Endogeneity, Heterogeneity and the Control Function Approach. $A E R C$, Nairobi.

36. Katz L., J. Kling and J.Liebman (2001). Moving to opportunity in Boston: Early Results of a Randomized Mobility Experiment. The Quartely Jornal of Economics 116 (2), 607-654.

37. Kioko M. U. (2009). The Economic Burden of Malaria in Kenya: A Household Level Investigation. $\mathrm{PhD}$ Thesis, University of Nairobi. 
38. Krishna A. 2006. Pathways Out of and Into Poverty in 36 Villages of Andhra Pradesh, India', World Development Vol. 34, No. 2, pp. 271-288.

39. Lawson D. (2004). A Microeconomic Analysis of Health, Health Care and Chronic Poverty. Unpublished, The university of Nottingham.

40. Lépine A. and A. Nestour (2008). Health Care Utilization in Rural Senegal: the Factors before the Extension of Health Insurance to farmers. International labor office, Research Paper,no.2.

41. Lindelow M. (2002). Health Care Demand in Rural Mozambique: Evidence from 1996/97. Household Survey. International Food Policy Research Institute (IFPRI), FCND, Discussion Paper, No. 126.

42. Litvack J. I. and C. Bodart (1993). User fees plus quality equals improved access to health care: Results of a field experiment in Cameroon. Soc Sci Med ; 37: 369-83.

43. Manning W. G., J. P. Newhouse, N. Duan, E. B. Keeler and A. Leibowitz (1987). Health Insurance and the Demand for Medical Care: Evidence from a Randomized Experiment. American Economic Association Review, Vol 77, No.3.

44. Manji J.E., S. F. Moses, N.J. Bradley, M.A. Nagelkerke, and F.A. Plummer (1992). Impact of user fees on attendance at a referral centre for sexually transmitted diseases in Kenya. Lancet ; 340: 463-6.

45. Mathers C.D. (1999). Gains in health expectancy from the elimination of diseases among older people. Disabil Rehabilitation, Vol 21(5-6):211-21.

46. Meer J. and S. R. Harvey, (2004). Insurance and the utilization of medical services. Social Science \& Medicine 58, 1623-1632.

47. McKeown T. (1976). The role of medicine: dream, mirage or nemesis? Oxford: Basil Blackwell.

48. Meza D. (1983). Health insurance and the demand for health care. Journal of Health Economics 2: 47-54.

49. Miller L. (1994). Medical Schools Put Women in Curricula. The Wall Street Journal, p. B1.

50. Ministry of Health (MoH), Republic of Rwanda, (2009). Health sector strategic plan.Unpublished.

51. Ministry of Health Rwanda, (2009). Rwanda Health Financing Policy Review of Rwanda-options for Universal Coverage 2009, World Health Organization.

52. Ministry of Health $(\mathrm{MoH})$, Rwanda Health Statistics Booklet 2011. Annual health statistics booklet 2011. Kigali, Unpublished.

53. Ministry of Health (MoH), Republic of Rwanda (2012). Annual report 2011. Kigali, Unpublished. 
54. Ministry of Health $(\mathrm{MoH})$, Rwanda Health Statistics Booklet 2013. Annual health statistics booklet 2013. Kigali, Unpublished.

55. Mocan N. H., E. Tekin and S. Z. Jeffrey (2004). The Demand for Medical Care in Urban China. World Development, Vol. 32, No. 2, pp. 289-304, 2004.

56. Mwabu G. J., B.Wang'ombe and B. Nganda (2003). The Demand for Medical Care in Kenya. African Development Bank, Oxford, OX4 2DQ, UK and 350 Main Street, Malden, MA 02148, USA.

57. National Institute of Statistics of Rwanda (NISR), (2011). Preliminary results of interim

58. demographic and health survey 2010, Kigali: NISR.

59. Nyman J. A. (2005). Health Insurance Theory: The Case of the Missing Welfare Gain, University of Minnesot, Unpublished.

60. Nusselder W.J., K. Van der Velveb, J.L.A., Sonsbeek, M.E. Lenior, G.A.M. Van den Bos. (1996). The Elimination of selected Chronic Deseases in a Population: The Compression and Expansion of Morbidity. American Journal of Public Health: 86:187-193.

61. Oxaal Z. and S. Cook (1998). Health and Poverty Gender Analysis. Swedish International Development Co-operation, Unpublished.

62. Phelps, C.E., and J. P. Newhouse. (1974). Coinsurance, the Price of Time, and the Demand for Medical Service. Review of Economics and Statistics 56, pp. 334-42.

63. Rashad I.K. and Markowitz S. (2009). Incentives in Obesity and health Insurance. Inquiry, Vol 46:418-432.

64. Republic of Rwanda (2010). United Nations General Assembly Special Session on HIV and AIDS', Country Progress Report January 2008-December 2009, Unpublished.

65. Ridde V. (2003). Fees-for-services, cost recovery, and equity in a district of Burkina Faso operating the Bamako Initiative. Bull World Health Organ; 81: 532-8.

66. Ringel, J. S., S. D.Hosek., A. V. Ben, and S. Mahnovski (2002.) The Elasticity of Demand for Health Care. A Review of the Literature and Its Application to the Military Health System. National Defense Research Institute, Unpublished.

67. Rosenzweig M. R., T. P. Schultz (1982). The Behavior of Mothers as Inputs to Child Health: The Determinants of Birth Weight, Gestation, and the Rate of Fetal Growth. 53-92, in: Fuchs, Victor R., ed., Economic Aspects of Health, Chicago: The University of Chicago Press.

68. Saksena P., K. Xu, R. Elovaino and J. Perrot (2010). Health Services Utilization and Out-of-Pocket Expenditure at Public and Private Facilities in Low-income Countries. Geneva: World Health Organisation, Background paper no. 20. 
69. Santerre R. E. and S. P. Neun (2010). Health Economics: theories, Insights and Industry Studies, $5^{\text {th }}$ edition, SouthWestern, Cengage Learning.

70. Sauerborn R., A. Nougtara and E. Latimer (1994). The elasticity of demand for health care in Burkina Faso: differences across age and income groups. Health Policy and Planning, 9(2), 186192.

71. Schultz T. P. (2008). Population Policies, Fertility, Women's Human Capital, In Schultz T.P. and J. Strauss (2008) eds., Handbook of Development Economics, Vol. 4, Chapter 52. Elsevier, Amsterdam; North-Holland.

72. Shimeles A. (2010). Community Based Health Insurance Schemes in Africa: the Case of Rwanda. African Development Bank group, Working Paper, No. 120.

73. Stock J. H (2010). The Other Transformation in Econometric Practice: Tools for Inference. Journal of Economic Perspectives. Volume 24, Number 2pp. 83-94.

74. Staiger D. and J. H. Stock (1997). Instrumental Variables Regression with Weak Instruments. Econometrica, 65(3): 557586.

75. Strauss J. and T. Duncan (1995). Human Resources: Empirical Modeling of Household and Family Decisions. In J. Behrman and T. N. Srinivasan, eds, Handbook of Development Economics, Vol. 3A. Amsterdam: Elsevier Science, NorthHolland, 1883-2023.

76. Terza J., A. Basu and P. Rathouz (2008). Two-stage residual inclusion estimation: addressing endogeneity in health econometric modeling. Journal of Health Economics; 27(3):531-543.

77. Wooldridge, J.M. (2002). Econometric Analysis of CrossSection and Panel Data. Cambridge, MA:MIT Press.

78. World Bank (2001a). Worl dBank Development Report 20002001: Attacking Poverty, Oxford University Press, Washington, D.C. 20433, U.S.A.

79. Yoder, R. (1989). Are people willing and able to pay for health services? Social Science and Medicine, 29(1), 35-42.

APPENDIX TABLES

Table A1: Marginal Effects for the Determinants of Outpatient Care

\begin{tabular}{|l|l|l|l|l|}
\hline $\begin{array}{l}\text { Explanatory } \\
\text { variables }\end{array}$ & $\begin{array}{l}\text { Baseline } \\
\text { Model } \\
\text { Marginal } \\
\text { Effects }\end{array}$ & $\begin{array}{l}\text { z- } \\
\text { statistics }\end{array}$ & $\begin{array}{l}\text { 2SRI } \\
\text { Marginal } \\
\text { Effects }\end{array}$ & $\begin{array}{l}\text { z- } \\
\text { statistics }\end{array}$ \\
\hline $\begin{array}{l}\text { Household } \\
\text { income }\end{array}$ & 0.0004 & $3.46^{* * *}$ & 0.00083 & $3.09^{* * *}$ \\
\hline
\end{tabular}

98 Rwanda Journal Series B: Social Sciences, Volume 3, 2016 


\begin{tabular}{|c|c|c|c|c|}
\hline User fees & -0.081 & $-11.47 * * *$ & -0.170 & $21.46 * * *$ \\
\hline $\begin{array}{l}\text { Quality of } \\
\text { health care } \\
(=1)\end{array}$ & -0.0002 & -0.27 & -0.008 & -0.20 \\
\hline $\begin{array}{l}\text { Health } \\
\text { insurance } \\
(=1)\end{array}$ & 0.013 & $10.20 * * *$ & 0.942 & $1.99 *$ \\
\hline $\begin{array}{l}\text { Distance to } \\
\text { the health } \\
\text { facility }\end{array}$ & -0.012 & $-6.13 * * *$ & -0.535 & $-7.43 * * *$ \\
\hline $\begin{array}{l}\text { Household } \\
\text { size }\end{array}$ & -0.0004 & $-2.51 * *$ & 0.011 & 0.77 \\
\hline Age & 0.0003 & $2.56^{* *}$ & 0.005 & $2.13 * *$ \\
\hline Square age & -0.0002 & $-2.13 * *$ & -0.00004 & $-2.4 *$ \\
\hline Male $(=1)$ & -0.003 & $-4.38 * * *$ & 0.149 & $3.89 * * *$ \\
\hline Urban $(=1)$ & -0.006 & $-4.71 * * *$ & -0.391 & $-4.65 * * *$ \\
\hline $\begin{array}{l}\text { Kigali region } \\
(=1)\end{array}$ & -0.0008 & -0.46 & -0.37 & -1.25 \\
\hline $\begin{array}{l}\text { Southern } \\
\text { region }(=1)\end{array}$ & -0.001 & -1.27 & -0.28 & $-2.67 * *$ \\
\hline $\begin{array}{l}\text { Western } \\
\text { region }(=1)\end{array}$ & 0.0006 & 0.52 & 0.14 & $2.01 * *$ \\
\hline $\begin{array}{l}\text { Northern } \\
\text { region }(=1)\end{array}$ & 0.005 & $2.76^{* *}$ & 0.317 & $3.94 * * *$ \\
\hline Primary $(=1)$ & 0.0001 & $1.96^{*}$ & 0.001 & $1.98 *$ \\
\hline $\begin{array}{l}\text { Secondary } \\
(=1)\end{array}$ & 0.0004 & $2.5 * *$ & 0.023 & $2.1 *$ \\
\hline Tertiary $(=1)$ & 0.0006 & $2.67 *$ & 0.006 & 0.9 \\
\hline $\begin{array}{l}\text { Insurance } \\
\text { residuals }\end{array}$ & - & - & 0.0054 & $2.31 * *$ \\
\hline
\end{tabular}

Note: $* * *, * *$ and $*=$ significant at $1 \%, 5 \%$ and $10 \%$ level respectively Source: researcher's own construction 
Table A2: Determinants of Demand for Health Insurance, First Stage Regression (Demand for Outpatient Care Model)

\begin{tabular}{|l|l|l|l|}
\hline Explanatory variables & Estimates & Standard errors & z-statistics \\
\hline Employment status (=1) & 0.051 & 0.0064 & $7.9^{* * *}$ \\
\hline Household income & 0.0034 & 0.0004 & $8.5^{* * *}$ \\
\hline User fees & -0.0278 & 0.0231 & -1.2 \\
\hline Quality of health care (=1) & 0.0033 & 0.0069 & 0.47 \\
\hline $\begin{array}{l}\text { Distance to the health } \\
\text { facility }\end{array}$ & -0.0483 & 0.0108 & $-4.47^{* * *}$ \\
\hline Household size & -0.0132 & 0.00125 & $-10.58^{* * * *}$ \\
\hline Age & 0.0072 & 0.00078 & $9.2^{* * *}$ \\
\hline Age squared & -0.00006 & 0.00001 & $-6.0^{* * * *}$ \\
\hline Primary (=1) & 0.0023 & 0.0045 & $5.1^{* * *}$ \\
\hline Secondary (=1) & 0.0052 & 0.0085 & 0.611 \\
\hline Tertiary (=1) & 0.0023 & 0.0087 & 0.264 \\
\hline Male (=1) & 0.0068 & 0.0058 & 1.17 \\
\hline Urban (=1) & 0.0847 & 0.0138 & $6.13^{* * *}$ \\
\hline Kigali (=1) & -0.0385 & 0.0129 & $-2.98^{* * * *}$ \\
\hline Southern (=1) & 0.0624 & 0.0088 & $0.32^{* * *}$ \\
\hline Western (=1) & 0.0555 & 0.00878 & \\
\hline Northern (=1) & 0.325 & 0.0174 & \\
\hline Constant & & & \\
\hline Number & & & \\
\hline
\end{tabular}

Note: $* * *, * *$ and $*=$ significant at $1 \%, 5 \%$ and $10 \%$ level respectively.

Source: Researcher's own construction 